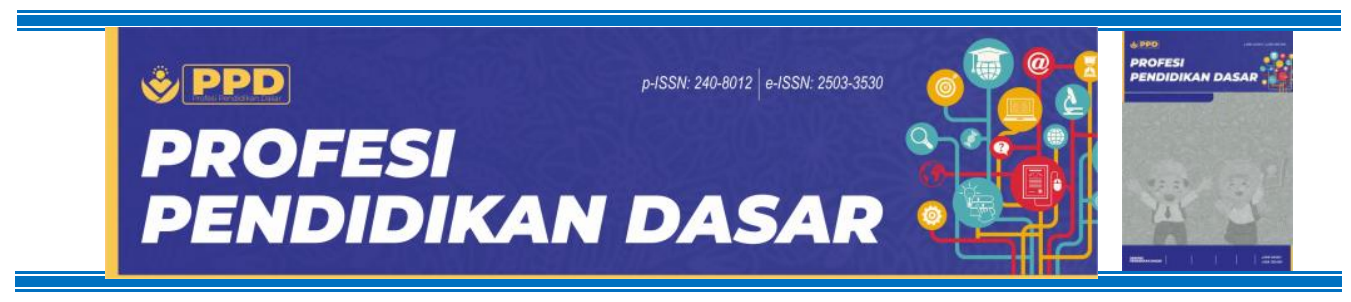

\title{
Implementasi Model Concept Attainment untuk Mengembangkan Kemampuan Pemecahan Masalah
}

\author{
Ratnawati Handayani $^{\mathbf{1}^{*}}$, \& Yulia Maftuhah Hidayati ${ }^{2}$ \\ ${ }^{1,2}$ Universitas Muhammadiyah Surakarta, Sukoharjo, Indonesia \\ Email \& Phone: ${ }^{*}$ ratnawati281098@gmail.com +6281328851727
}

\begin{tabular}{|c|c|}
\hline $\begin{array}{l}\text { Submitted: } 2020-09-03 \\
\text { Accepted: } 2020-12-03 \\
\text { Published: } 2020-12-20\end{array}$ & DOI: 10.23917/ppd.v7i2.12053 \\
\hline Keywords: & Abstract \\
\hline $\begin{array}{l}\text { Mathematics } \\
\text { Achievement } \\
\text { Model concepts } \\
\text { Problem solving }\end{array}$ & $\begin{array}{l}\text { This study aims to describe the implementation of concept attainment model } \\
\text { in developing math problem solving skills of } 5^{\text {th }} \text { grade elementary school } \\
\text { students. This study used a qualitative approach with a phenomological } \\
\text { research design. The subjects in this study were } 2 \text { students and } 1 \text { teacher of } 5^{\text {th }} \\
\text { grade of SD Negeri Newung } 2 \text { Elementary School (SDN Newung 2), Sukodono, } \\
\text { Indonesia. The data technique used tests and interviews with students and } \\
\text { teachers. The data validity used source and method triangulation. Data } \\
\text { analysis used three stages, namely (1) data reduction, (2) data presentation, } \\
\text { (3) data conclusions. The results of this study, (1) the students' mathematical } \\
\text { solving ability is good, because students have mastered the indicators of } \\
\text { mathematical problem solving abilities, (2) Implementation of the concept } \\
\text { attainment model in Mathematics learning is correct, because students are } \\
\text { enthusiastic about learning, the steps used are appropriate, namely the stage } \\
\text { of analyzing thinking strategies, presenting data, and testing concept } \\
\text { achievement. }\end{array}$ \\
\hline
\end{tabular}

\section{PENDAHULUAN}

Matematika bukan hanya mempelajari hal kognitif/pengetahuan saja, namun dalam belajar matematika siswa juga mendapatkan kemampuan matematis. Kemampuan matematis yang dimaksud seperti yang ditetapkan dalam (NCTM 2000) yaitu, standar kemampuan matematis yang siswa wajib punya sebagai berikut: (1) kemampuan pemecahan masalah, (2) komunikasi matematis, (3) kemampuan koneksi, (4) kemampuan penalaran, dan (5) kemampuan representasi. Dari lima standar kemampuan matematis tersebut, kemampuan pemecahan masalah ialah satu hal penting bagi siswa.

Melalui pemecahan masalah, siswa dibiasakan untuk melihat masalah bukan hanya dari satu sisi saja. Magdalena dan Surya (2018) mengungkapkan bahwa pemecahan masalah adalah salah satu komponen kurikulum matematika yang digunakan saat kegiatan belajar mengajar dan juga dalam penyelesaian soal, hal ini dikarenakan dengan pemecahan masalah siswa mampu mendapatkan pengalaman yang memerlukan pengetahuan dan juga ketrampilan yang mampu dikuasai, kemudian dapat diaplikasikan pada soal tidak rutin. Melalui kegiatan ini diharapkan kemampuan matematika misalnya, penemuan pola, penggeneralisasian dan komunikasi matematika, pemecahan pada masalah tidak rutin dapat dikembangkan secara lebih baik

Pemecahan masalah merupakan suatu keterampilan minimal dalam matematika yang harus dikuasasi siswa untuk dapat menjalankan fungsinya dalam lingkungan masyarakat (Ahmad dan Susanto, 2013:134). Hal ini didukung dengan adanya penjelasan pemecahan 
Handayani ${ }^{1}$, \& Hidayati ${ }^{2}$ - Implementasi Model Concept Attainment ...

masalah yang diungkapkan oleh NCTM (2000) yaitu proses pengaplikasian pengetahuan yang sudah diproleh sebelumnya pada keadaan yang baru serta berbeda.

NCTM merupakan dewan perkumpulan guru matematika seluruh dunia yang memiliki tujuan untuk mensupport guru dalam menegaskan bahwa matematika itu adil, pembelajaran terbaik untuk semua siswa dengan visi, kepemimpinan, pengembangan profesional, dan penelitian. Adapun menurut NCTM (2000) indikator-indikator yang diperlukan dalam mengetahui kemampuan pemecahan masalah matematika sebagai berikut: (1) Mengidentifikasi data yang diketahui, ditanyakan, dan sudah cukupnya data yang diperlukan dalam soal matematika., (2) Menyusun model matematika yang digunakan untuk penyelesaian., (3) Menerapkan rencana/model matematika untuk menyelesaikan berbagai masalah matematika atau diluar matematika., (4) Menjelaskan jawaban/hasil berdasarkan asal masalah., (5) Menggunakan matematika dengan bermakna.

Pemecahan masalah ialah suatu proses berpikir untuk menyelesaikan permasalahan. Selain itu, pemecahan masalah adalah pemakaian metode dalam kegiatan pembelajaran dengan memberikan siswa pengetahuan untuk menerima suatu permasalahan baik masalah individu atau masalah kelompok, untuk diselesaikan secara individu atau bersama-sama. Menurut Polya (2004) tahap-tahap dalam pemecahan masalah antara lain, (1) memahami suatu masalah, (2) membuat rencana penyelesaian, (3) melakukan rencana, (4) melihat kembali. Adanya keterangan-keterangan tersebut kesimpulanya yaitu pemecahan masalah memiliki tahapan seperti berikut, (1) mengidentifikasi dan memahami suatu persoalan/masalah, (2) merencanakan penyelesaian suatu masalah, (3) melaksanakan rencana, (4) menjelaskan hasil, (5) melihat kembali.

Hasil studi TIMSS (Trends in International Mathematics and Science Study) peringkat Indonesia berada diposisi bawah dari tahun ke tahun, seperti tahun 2011 Indonesia di peringkat 38 dari 46 negara dengan skor 375. Begitu pula dengan Hasil TIMSS pada tahun 2015 yang dipublkasikan pada desember 2016 berada diperingkat 46 dari 51 negara dengan skor 397. Hal tesebut memperlihatkan bahwa di Indonesia kemampuan pemecahan masalah matematikanya masih rendah.

Untuk mengatasi rendahnya kemampuan pemecahan masalah matematika yang berada di Indonesia diperlukan untuk menerapkan sebuah model pembelajaran. Model pembelajaran sendiri memiliki pengertian sebuah rencana yang berfungsi sebagai acuan untuk membuat perencanaan kegiatan belajar mengajar di kelas. Dalam memilih model pembelajaran terdapat beberapa acuan, yaitu mengacu pada pendekatan pembelajaran yang digunakan di kelas yang didalamnya terdapat tujuan pengajaran, langkah-langkah dalam kegiatan belajar mengajar, suasana yang digunakan dalam pembelajaran, dan juga pengelolaan di dalam kelas (Kholifah dan Kurniawan, 2016). Ada berbagai macam model pembelajaran, namun model concept attainment dapat menjadi alternatif untuk menjadikan siswa memahami gambaran konsep pembelajaran, karena model ini dirancang untuk menyusun informasi sehingga, macam-macam konsep yang penting bisa dipelajari dengan efektif serta efisien (Joyce, Weil, dan E.C., 2016).

Model ini juga dapat membuat siswa lebih antusias dalam belajar, baik menerapkan maupun menghubungkan konsep secara bersamaan, untuk menghasilkan pencapaian yang lebih baik (Habib, 2019). Adapun juga model concept attainment merupakan suatu model pembelajaran yang tepat untuk memperlihatkan suatu data informasi yang sudah diorganisir dengan sebuah hal yang luaa dan lebih mudah dimengerti untuk tingkatan perkembangan konsep (Putri 2017). 
Penerapan model ini memusatkan pada dua hal, antara lain pengembangan sebuah konsep, dan sebuah korelasi antara konsep yang terkait erat untuk latihan dalam berpikir kritis (Muhammad, Djufri, dan Muhibbudin 2014). Hal ini didukung dengan penelitian yang dilaksanakan oleh Munir et al., (2017) pada siswa kelas XI SMA NU Palembang, model concept attainment mempengaruhi berpikir kritis pada anak karena siswa menemukan suatu konsep dari materi pembelajaran.

Penelitian mengenai model concept attainment sebelumnya pernah dilakukan oleh beberapa peneliti. Angraini (2019) mengungkapkan bahwa model concept attainment mampu memberikan pengaruh yang baik dalam kemampuan matematis dan berpikir kritis siswa. Kemudian, hasil penelitian Putri (2017) menggunakan model concept attainment untuk mengukur tingkat pemahaman konsep matematika siswa. Penelitian yang dilakukan oleh Habib (2019) mengenai model concept attainment mempengaruhi hasil prestasi mata pelajaran sosial siswa. Lalu, dilakukan oleh (Sijabat et al. 2019) menggunakan model concept attainment untuk mengetahui aktivitas matematika siswa.

Penelitian oleh Muhammad et al. (2014) mengungkapkan bahwa model concept attainment dapat meningkatkan hasil belajar siswa pada mata pelajaran biologi materi metabolism. Kemudian, Kaur (2018) mengungkapkan bahwa model concept attainment dapat meningkatkan prestasi siswa dalam mata pelajaran kimia. Begitu pula, Bhargava (2015) menuturkan bahwa model concept attainment dapat meningkatkan prestasi sosial siswa kelas VIII.

Penelitian Kumar dan Mathur (2013) menuturkan bahwa model concept attainment dapat mempengarusi akusisi fisika siswa, kemudian penelitian yang dilakukan Anjum (2014) yaitu membandingkan pemahaman konsep geometri siswa pada materi geometri. Kiswandi, Soedjoko, dan Hendikawati (2013) melakukan penelitian mengenai model concept attainment pemehaman siswa lebih baik dibandingkan dengan model cognitive growth. Sedangkan, penelitian ini membahas tentang model concept attainment untuk mengembangkan kemampuan pemecahan masalah matematika di kelas $\mathrm{V}$.

Berdasarkan hal tersebut, peneliti melakukan penelitian tentang "Implementasi Model Concept Attainment untuk Mengembangkan Kemampuan Pemecahan Masalah". Tujuan dari penelitian ini yaitu, untuk mendeskripsikan implementasi model concept attainment dalam mengembangkan kemampuan pemecahan masalah matematika siswa kelas V SD.

\section{METODE}

Penelitian yang digunakan adalah pendekatan kualitatif. Penelitian kualitatif merupakan jenis penelitian dengan berlandaskan filsafat positivisme, pendekatan ini diperlukan pada kondisi objek yang alamiah, dalam penelitian peneliti mempunyai peran sebagai instrument kunci, menggunakan teknik triangulasi untuk mengumpulkan data, analisis data bersifat induktif atau kualitatif serta hasil penelitian dari pendekatan kualitatif lebih berfokus ke pemahaman makna (Sugiyono, 2018:15) dan dengan desain penelitian fenomenologi. Penelitian ini berlangsung di SD Negeri Newung 2 yang terletak di dusun Pohjaring, RT. 01 RW. 02 desa Newung, kecamatan Sukodono, kabupaten Sragen, Jawa Tengah, 57263. Penelitian ini dilakukan di kelas $V$ karena sudah menerapkan selama 3 bulan model concept attainment dalam pembelajaran matematika dalam materi bangun ruang. Narasumber untuk penelitian ini ialah 2 siswa dan 1 guru kelas V SD Negeri Newung 2.

Teknik pengumpulan data untuk penelitian ini menggunakan wawancara dan tes. Tes dikerjakan oleh siswa yang terdiri 5 pertanyaan mengenai pemecahan masalah dengan materi kubus dan balok pada KD 3.5 dan 4.5, tes ini digunakan untuk melihat kemampuan siswa dalam menguasai indikator kemampuan pemecahan masalah matematika. Kemudian, dilakukan wawacara dengan siswa mengenai jawaban dari soal tes yang sudah 
Handayani ${ }^{1}$, \& Hidayati ${ }^{2}$ - Implementasi Model Concept Attainment ...

dituliskan dan mengenai pembelajaran model concept attainment yang sudah dilaksanakan dalam pembelajaran matematika, begitu pula wawancara yang dilakukan dengan guru mengenai pembelajaran model concept attainment dalam pembelajaran matematika. Kemudian, teknik keabsahan datanya menggunakan triangulasi sumber, peneliti melibatkan lebih dari satu sumber untuk mendapatkan data yaitu wawancara dengan guru dan siswa. Lalu, triangulasi teknik/metode peneliti menggunakan satu sumber saja namun dengan teknik berbeda wawancara dan tes. Data penelitian ini akan dianalisis dengan tiga tahap, antara lain: (1) reduksi data, yaitu peneliti merangkum data penelitian, (2) penyajian data, yaitu peneliti menyusun data hingga menghasilkan gambaran penelitian, (3) kesimpulan/ verifikasi data, yaitu peneliti menemukan makna dari penelitian.

\section{HASIL DAN PEMBAHASAN}

Penelitian ini menyampaikan secara menyeluruh mengenai implementasi model concept attainment untuk mengembangkan kemampuan pemecahan masalah siswa kelas V. Penelitian ini dilaksanakan di SD Negeri Newung 2 yang sudah menerapkan model concept attainment di kelas $V$ dan menggunakan wawancara, tes tertulis dan dokumentasi untuk mendapatkan datanya. Penelitian ini mengambil sampel 2 siswa kelas $\mathrm{V}$, masingmasing siswa diberikan 5 soal mengenai kemampuan pemecahan masalah matematika dengan materi bangun ruang kubus dan balok. Selanjutnya, dilanjutkan wawancara dengan siswa dan guru mengenai model concept attainment.

Kemampuan pemecahan masalah matematika siswa bisa diketahui dari hasil tes yang sudah dikerjakan siswa. Untuk menganalisis seberapa menguasainya siswa dalam mengerjakan tes pemecahan masalah dapat diidentifikasi dari indikator kemampuan pemecahan masalah itu sendiri. Indikator tesebut yaitu, memahami masalah (siswa menyebutkan yang diketahui dan ditanya), merencanakan penyelesaian (siswa menuliskan rumus yang sesuai dengan permasalahan dalam soal), melakukan rencana (siswa memasukkan data yang diperoleh ke dalam rumus yang sudah ditentukan, siswa melaksanakan penyelesaian dengan tahap yang runtut dan penghitungan yang benar, siswa menyimpulkan hasil penyelesaian.), dan melihat kembali (siswa mampu melihat kembali pekerjaannya). Jawaban untuk soal nomor 1 dari kedua subjek S1 dan S2 dapat dilihat berikut ini (lihat Gambar 1).

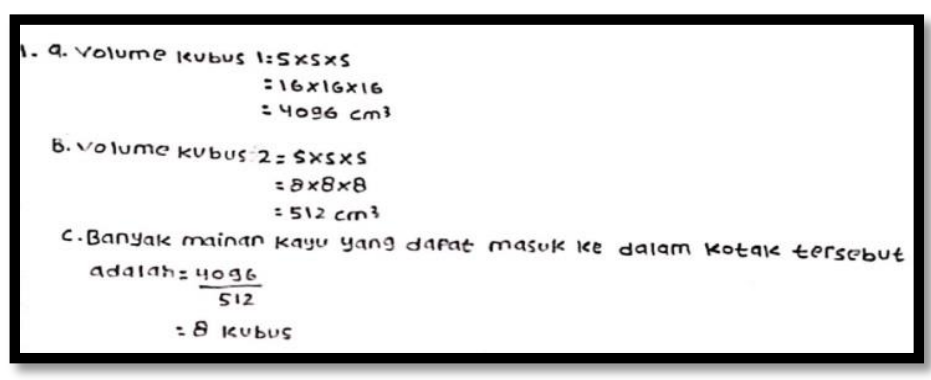

Gambar 1. Hasil Pekerjaan S1.

Berdasarkan jawaban S1, dapat diketahui S1 mengetahui data yang diketahui dan yang ditanyakan, S1 dapat menuliskan rumus dan mengaplikasikannya secara tepat, kemudian siswa juga mampu menyimpulkan jawaban dengan tepat serta mengecek kembali. Sehingga, dapat ditarik kesimpulan yaitu S1 menguasai semua indikator kemampuan 
pemecahan masalah matematika dalam soal ini. Hal ini didukung dengan wawancara sebagai berikut:

$P$ : Apakah kamu memahami soal nomor 1 dan jawabannya?

S1 : Paham Bu. Dalam soal ini yang diketahui ada kotak yang berbentuk kubus dan mainan kayu yang berbentuk kubus juga tetapi ukuran mainan kayu lebih kecil lalu yang dicari berapa banyak mainan kayu yang dapat dimasukkan dalam kotak. Selanjutnya dicari volume kubus besar dan keci rumusnya $\mathrm{V}=$ sisi $x$ sisi $x$ sisi, lalu hasilnya volume kotak dibagi volume kubus nanti ketemu jawabannya yaitu 8 mainan kayu dapat masuk kedalam kotak bu. Saya cek kembali apa yang sudah saya kerjakan.

Berdasarkan hasil wawancara dengan S1 dapat ditinjau, S1 memang memahami permasalahan yang berada dalam soal, lalu juga mampu mengaplikasikan rumus, menyelesaikan permasalahan dengan jawaban yang tepat, dan mengecek kembali. Sehingga dapat disimpulkan bahwa S1 menguasai indikator dalam tahapan kemampuan pemecahan masalah matematika yang berada dalam soal. Sedangkan, untuk jawaban S2 sebagai berikut (lihat Gambar 2).

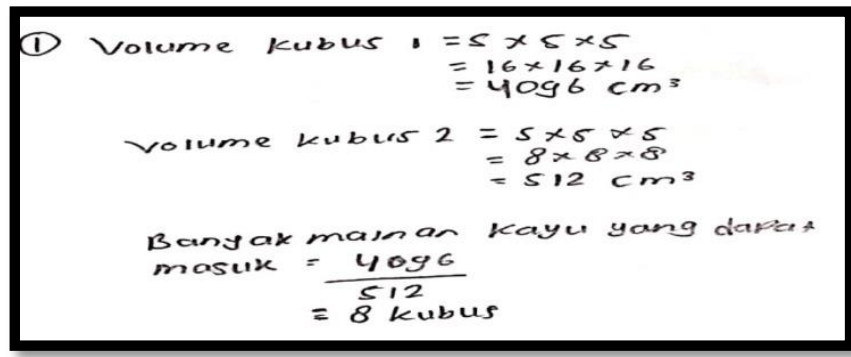

Gambar 2. Hasil Pekerjaan S2

Berdasarkan jawaban S2, apat ditinjau bahwa S2 mampu menyebutkan yang diketahui dan ditanyakan, kemudian menuliskan rumus dan memasukkan data ke dalam rumus dengan benar. S2 juga menyimpulkan jawaban dengan benar dan mengeceknya kembali. Hal ini membuktikan bahwa S2 sudah menguasai indikator kemampuan pemecahan masalah untuk soal ini. Uraian ini didukung dengan wawancara sebagai berikut.

$P$ : Apakah kamu memahami soal nomor 1 dan jawabannya?

S2 : Paham Bu. diketahui ada kotak kubus besar dan mainan kayu kubus kecil. pertanyaannya mencari banyaknya mainan kayu yang dapat masuk ke dalam kotak, cara mencari banyaknya mainan kayu yang dapat dimasukkan ke dalam kotak yaitu mencari volume kotak kemudian dibagi dengan volume mainan kayu. Kotaknya berbentuk kubus berarti memakai rumus volume: sisi $x$ sisi $x$ sisi. Dan Sudah saya cek kembali.

Berdasarkan wawancara dengan S2, dapat ditinjau S2 mampu mengutarakan yang diketahui dan ditanyakan, kemudian menjelaskan rumus dan memasukkan data dengan benar. S2 juga menyimpulkan jawaban dengan benar dengan mengeceknya kembali. Dapat disimpulkan bahwa siswa menguasai indikator kemampuan pemecahan masalah untuk soal ini. 
Handayani ${ }^{1}$, \& Hidayati ${ }^{2}$ - Implementasi Model Concept Attainment ...

Uraian di atas mengenai jawaban S1 dan S2 pada soal nomor 1 dapat diketahui bahwa siswa mampu menguasai indikator kemampuan pemecahan masalah matematika. Kemudian, untuk soal nomor 2 hasil pekerjaan siswa bisa diketahui sebagai berikut (lihat Gambar 3).

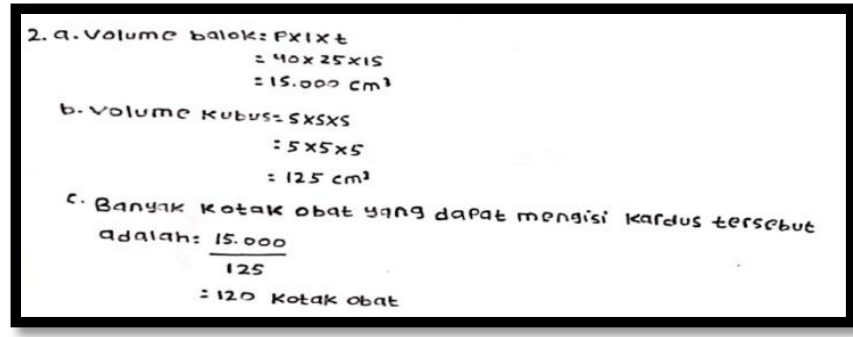

Gambar 3. Hasil Pekerjaan S1

Berdasarkan jawaban S1, dapat dilihat bahwa S1 mampu mengidentifikasi data diketahui dan ditanyakan dalam soal. S1 juga dapat menuliskan rumus dan menyelesaikannya dengan benar, lalu dalam membuat kesimpulan siswa juga menjelaskan dengan benar dan S1 melihat kembali hasil pekerjaannya. Sehingga, bisa disimpulkan bahwa S1 sudah menguasai indikator kemampuan pemecahan masalah yang berada dalam soal ini. Hal ini didukung dengan wawancara sebagai berikut

\section{$P$ : Apakah kamu memahami soal nomor 2 beserta jawabannya?}

S1 : Paham Bu. Soal ini mencari banyaknya kotak obat yang bisa masuk ke dalam kotak berbentuk balok. Yang diketahui ada kotak yang berbentuk balok dan kotak obat (kubus). Selanjutnya dicari volumekotak dan kotak obat rumusnya dengan volume balok adalah $V=$ panjang $x$ lebar $x$ tinggi dan volume kubus adalah $V=$ sisi $x$ sisi $x$ sisi, lalu hasilnya volume kotak dibagi volume kubus nanti ketemu jawabannya yaitu ada 120 kotak obat yang dapat masuk ke dalam kotak balok. Sudah saya cek kembali jawaban saya.

Berdasarkan wawancara tersebut S1 mampu menjelaskan data yang berada disoal dan pertanyaannya. Lalu, S1 mampu menuliskan dan mengaplikasikan data ke dalam rumus dengan benar. Selanjutnya S1 menyimpulkannya secara tepat dan mengecek kembali pekerjaannya. Sehingga, penyimpulannya yaitu S1 sudah menguasai setiap indikator dalam tahapan kemapuan pemecahan masalah yang berada dalam soal ini. Sedangkan, untuk jawaban S2 dapat dilihat sebagai berikut (lihat Gambar 4).

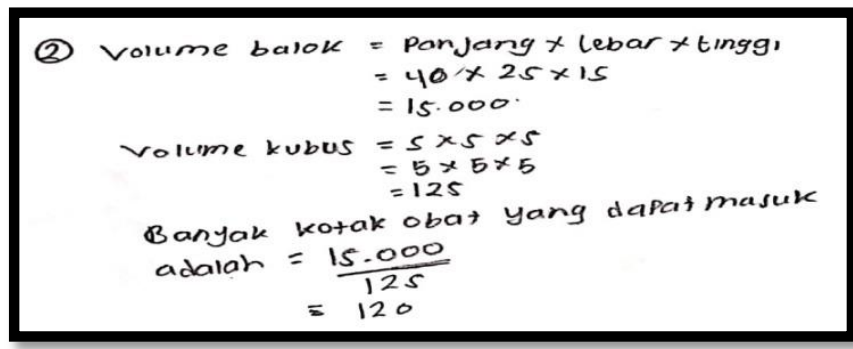

Gambar 4. Hasil pekerjaan S2 
Berdasarkan jawaban S2 di atas siswa dapat ditinjau bahwa S2 mampu menyebutkan data yang ada dalam soal, penulisan rumus dan mengaplikasikannya dengan tepat, serta menyimpulkan jawaban dengan benar, dan S2 mengecek kembali jawabannya. Hal ini menunjukkan bahwa S2 sudah menguasai indikator kemampuan pemecahan masalah matematika.

$P$ : Apakah kamu memahami soal nomor 2 beserta jawabannya?

S2 : Paham Bu. diketahui kotak berbentuk balok dan kotak obat berbentuk kubus, dalam soal ini mencari banyaknya kotak obat yang dapat dimasukkan ke dalam kotak besar, awalnya mencari volume balok dengan rumus $v=p \times I \times t$, setelah itu dicari volume kubus dengan rumus $v=s \times s \times s$. Kemudian untuk mencari banyaknya kotak obat yang dapat masuk ke dalam kotak dengan cara volume balok dibagi volume kubus. Hasilnya banyaknya kotak obat adalah 120 buah. Dan sudah saya cek kembali jawaban saya.

Berdasarkan wawancara dengan S2 dapat dilihat bahwa S2 mampu menyebutkan yang diketahui dan ditanyakan, kemudian menjelaskan rumus dan mengaplikasikan data ke rumus dengan benar. Setelah itu dapat disimpulkan yaitu siswa menguasai indikator kemampuan pemecahan masalah untuk soal ini.Dari uraian mengenai soal nomor 2 yang sudah dikerjakan oleh S1 dan S2 dapat diketahui bahwa S1 dan S2 sudah menguasai indikator kemampuan pemecahan masalah matematika dalam soal ini. Selanjutnya, untuk soal nomor 3 dapat dilihat jawaban siswa seperti berikut (lihat Gambar 5).



Gambar 5. Hasil pekerjaan S1

Berdasarkan Gambar 5, dapat dilihat bahwa S1 mampu menyebutkan yang diketahui dan ditanyakan dalam soal, S1 mampu menyebutkan rumus dan mengaplikasikan data ke dalam rumusnya dengan tepat, S1 juga menyimpulkan jawaban dan mengecek kembali jawabannya. Sehingga, dapat ditarik kesimpulan bahwa S1 menguasai indikator dalam kemampuan pemecahan masalah untuk soal ini.

$P$ : Apakah memahami soal nomor 3 dengan penyelesaiannya?

S1 : Saya paham Bu. Dalam, soal ini yang diketahui volumenya, panjang dan lebar dari bak mandi berbentuk balok. Lalu, yang ditanyakan adalah berapa lebar dari bak mandi ini. Untuk menyelesaikan saya masukkan ke dalam rumusnya kemudian lebar dapat dicari dengan volume dibagi panjang $x$ tinggi. Dan saya sudah mengecek kembali bu.

Berdasarkan wawancara dengan SI, dapat dilihat bahwa S1 mampu menjelaskan tentang permasalahan dalam soal ini dengan menyebutkan yang diketahui, ditanyakan dalam soal, S1 mampu menyebutkan rumus dan menjelaskan pengerjaannya rumusnya, menyimpulkan jawaban dan mengecek kembali jawaban. Sehingga, dapat ditarik 
Handayani ${ }^{1}$, \& Hidayati ${ }^{2}$ - Implementasi Model Concept Attainment ...

kesimpulan bahwa S1 menguasai indikator dalam kemampuan pemecahan masalah untuk soal ini. Dan jawaban S2 sebagai berikut (lihat Gambar 6).

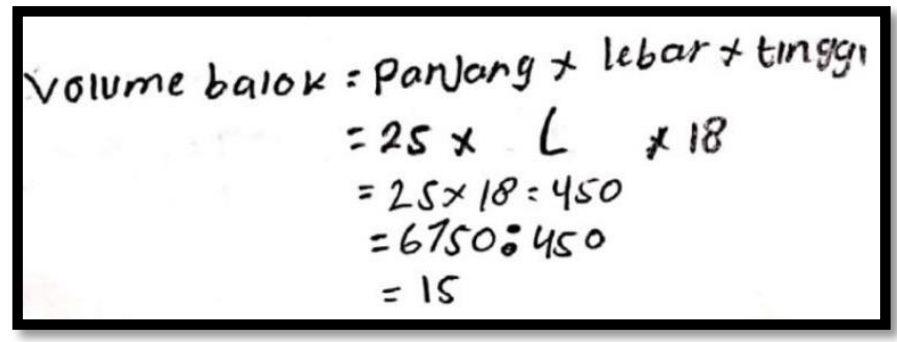

Gambar 6. Hasil pekerjaan S2

Berdasarkan jawaban S2 sudah menjawab soal tepat. S2 mampu menyebutkan yang diketahui dan ditanyakan, siswa mampu menuliskan rumus dan mengaplikasikandatanya dengan tepat. S2 juga mampu menyimpulkan jawaban dengan benar. Sehingga, dapat disimpulkan bahwa S2 sudah menguasai indikator kemampuan pemecahan masalah matematika untuk soal ini.Tetapi, untuk menunjukkan pernyataan tersebut dapat dilihat wawancara sebagai berikut.

$P$ : Apakah kamu memahami soal nomor 3 dengan penyelesaiannya?

S2 : Saya paham Bu. diketahui ada bak mandi berbentuk balok dengan volume, panjang dan tinggi. Dicari lebar dari balok ini, Kemudian dalam mencari lebar balok memerlukan rumus $v=p \times I \times t$, data dimasukkan kemudian hasilnya lebar balok adalah $15 \mathrm{~cm}$. Tetapi saya tidak mengecek kembali jawaban saya.

Berdasarkan wawancara dengan S2 dapat ditinjau yakni S2 dapat menyebutkan yang diketahui dan ditanyakan dalam soal. S2 mampu menjelaskan rumus balok dan mengaplikasikan data ke dalam rumus dengan penyimpulan jawaban dengan tepat. Maka dari itu, kesimpulannya adalah siswa sudah menguasai indikator dalam kemampuan pemecahan masalah matematika untuk soal ini. Pada soal nomor 3 S1 dan S2 sudah mampu menguasai indikator dalam kemampuan pemecahan masalah matematika yang ada dalam soal ini. Untuk soal nomor 4 dapat dilihat jawaban siswa seperti berikut (lihat Gambar 7).



Gambar 7. Hasil pekerjaan S1 
Berdasarkan jawaban S1, dapat ditinjau bahwa S1 mampu menyebutkan hal yang diketahui dan ditanyakan dalam soal, S1 mampu menuliskan rumus dan memasukkan data ke dalam rumus dengan baik, S1 menyimpulkan dengan benar hasil yang diperoleh dan mengecek kembali jawabannya. Hal ini membuktikan, bahwa S1 sudah menguasai indikator kemampuan pemecahan masalah matematika untuk soal ini. Untuk membuktikan pernyataan tersebut maka dilakukan wawancara sebagai berikut

$P$ : Apakah kamu memahami maksud dari soal nomor 4?

S1 : Saya paham Bu. Soal ini diketahui luas alas, volume, dan lebar aquarium. Lalu, ditanyakan tinggi aquarium ini, caranya ya dimasukkan ke dalam rumus seperti ini, lalu tinggi aquarium dapat dicari dengan volume dibagi luas alas bu. Saya mengeceknya kembali bu.

Berdasarkan wawancara dengan S1 tersebut dapat ditinjau bahwa S1 dapat menyebutkan hal yang diketahui dan ditanyakan dalam soal, mampu menuliskan rumus dan memasukkan data ke dalam rumus dengan baik, S1 menyimpulkan dengan benar hasil yang diperoleh dan mengeceknya kembali. Hal ini membuktikan bahwa S1 cukup menguasai indikator kemampuan pemecahan masalah matematika untuk soal ini. Dan untuk jawaban S2 dapat dilihat sebagai berikut (lihat Gambar 8).

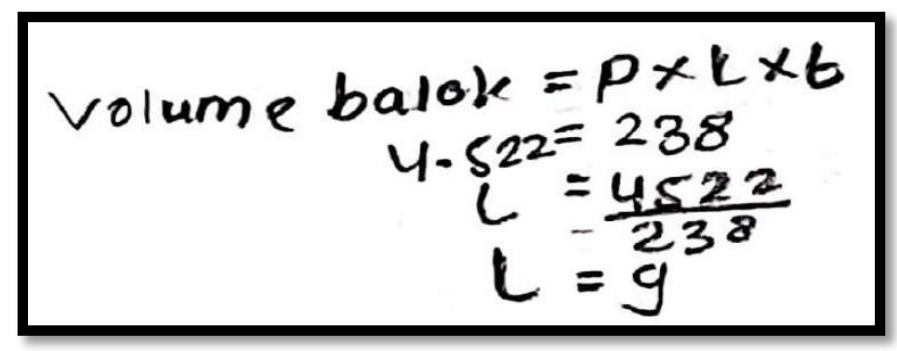

Gambar 8. Hasil pekerjaan S2

Berdasarkan jawaban S2, dapat dilihat bahwa S2 dapat menyebutkan yang diketahui dan ditanyakan, S2 mampu menuliskan rumus, tetapi memasukkan data informasi ada kesalahan. S2 juga tidak menyimpulkan jawaban dengan benar. Dapat disimpulkan bahwa siswa cukup menguasai indikator kemampuan pemecahan masalah untuk soal ini. Untuk menguatkan pernyataan tersebut dapat dilihat hasil wawancara sebagai berikut.

P : Apakah kamu memahami maksud dari soal nomor 4?

S2 : Paham Bu. didalam soal ini terdapat luas alas, volume dan lebar aquarium. Tinggi dari aquarium perlu dicari, mengerjakannya dengan cara menggunakan rumus volume balok $v=p \times I \times t$. Dan saya tidak mengeceknya kembali bu.

Pada soal nomor 4 S2 sudah menguasai indikator dalam kemampuan pemecahan masalah matematika, namun S2 hanya mengasai 3 indikator saja karena dalam penyimpulan jawaban S2 kurang tepat dan tidak mengecek kembali jawabannya. Kemudian, untuk jawaban nomor 5 dari kedua subjek dapat ditinjau sebagai berikut (lihat Gambar 9). 


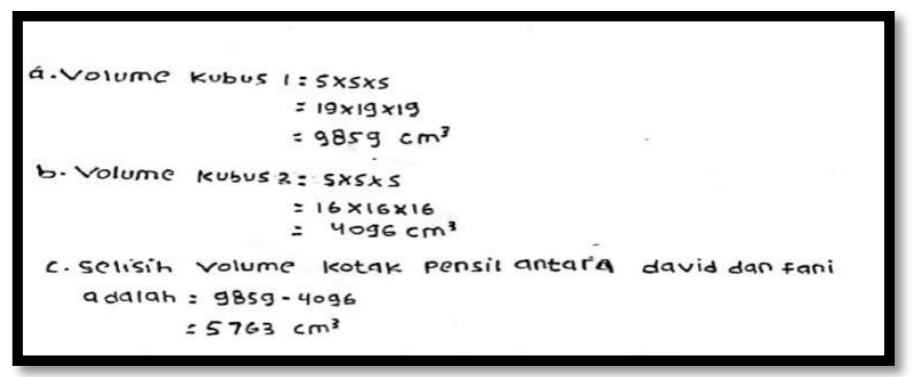

Gambar 9. Hasil pekerjaan S1

Berdasarkan jawaban, dapat dilihat bahwa S1 sudah mengetahui apa yang diketahui dan apa yang ditanyakan dan menuliskan rumus serta memasukkan data dengan tepat. Namun, dalam poin a siswa kurang teliti dalam mengerjakan soal sehingga jawabannya salah. Poin b S1 menjawab benar dan poin c yang merupakan kesimpulan S1 menjawab salah. Ini membuktikan bahwa siswa cukup memahami beberapa indikator dalam kemampuan pemecahan masalah. Untuk menguatkan pernyataan berikut adalah hasil wawancara dengan S3 sebagai berikut:

\section{$P$ : Apakah anda paham dengan soal nomor 5 ?}

S1 : Saya paham Bu. Di dalam soal ini mencari selisih volume kubus 1 dan volume kubus 2. Diketahui masing- masing sisi kubus lalu setelah dihitung menggunakan rumus barulah dicari selisish dengan mengurangi antara kubus 1 dan kubus 2. Tapi saya tidak mengecek ulang pekerjaan saya.

Berdasarkan wawancara dengan S2 tersebut dapat ditinjau bahwa S2 dapat menyebutkan hal yang diketahui dan ditanyakan dalam soal, mampu menuliskan rumus dan memasukkan data ke dalam rumus dengan baik, tetapi S2 tidak menyimpulkan dengan benar hasil yang diperoleh. Hal ini membuktikan bahwa S2 cukup menguasai indikator kemampuan pemecahan masalah matematika untuk soal ini. Selanjutnya jawaban S2 sebagai berikut (lihat Gambar 10)

$$
\begin{array}{rl|}
\text { volume kubusl: } 5 \times 5 \times 5 \\
=19 \times 19 \times 19 \\
=3249
\end{array} \mid \begin{aligned}
\text { volume kubur 2 } & =5 \times 5 \times 5 \\
& =16 \times 16 \times 16 \\
& =3136
\end{aligned}
$$

\section{Gambar 10. Hasil pekerjaan S2}

Berdasarkan jawaban siswa di atas. Siswa mampu menyebutkan yang diketahui dan ditanyakan dalam soal, S2 mampu menuliskan rumus rumus dan memasukkan data dengan benar. Namun, S2 tidak mampu menyimpulkan jawaban dengan benar karena dari penghitungannya saja siswa sudah melakuakn kesalahan dan untuk selishnya sendiri siswa tidak ditampilkan. Hal ini menunjukkan bahwa S2 cukup menguasai indikator kemampuan 
pemecahan masalah matematika.Tetapi, untuk menunjukkan pernyataan tersebut benar dapat dilihat dari hasil wawancara sebagai berikut.

\section{$P$ : Apakah anda paham dengan soal nomor 5 ?}

S2 : Sedikit Bu. Dalam soal ini terdapat sisi dari kotak pensil 1 dan kotak pensil 2. ditanyakan selisih abtara volume kotak pensil 1 dengan kotak pensil 2. Volume kubus = sisi $x$ sisi $x$ sisi data dimasukkan ke dalam rumus kemudian hasilnya dicari dengan volume kubus 1 dikurangi volume kubus 2.

Berdasarkan wawancara dengan S2 dapat dilihat bahwa S2 dapat mampu menjelaskan yang diketahui dan ditanyakan dalam soal S2 mampu menjelaskan rumus dan memasukkan data. Namun, siswa kurang teliti atas jawaban siswa karena tidak dicek kembali. Sehingga dapat disimpulkan bahwa siswa cukup menguasai indikator kemampuan pemecahan masalah yaitu memahami masalah, merencanakan masalah, dan melakukan rencana untuk soal ini.

Pada soal nomor 5 S1 dan S2 hanya menguasai indikator memahami masalah, merencanakan penyelesaian dan melakukan rencana saja, dalam tahap penyimpulan siswa tidak teliti sehingga mengalami kesalah. Dari hal ini dapat diimpulkan bahwa S1 sudah menguasai indikator kemampuan pemecahan masalah matematika untuk 4 soal dari 5 soal yang tersedia dapat. Sedangkan, S2 sudah menguasai 3 soal dari 5 soal yang tersedia dan S2 cukup menguasai indicator dalam kemampuan pemecahan masalah matematika.

Berdasarkan hasil tes tersebut dapat diketahui bahwa kemampuan pemecahan masalah siswa sudah berlangsung selama 3 bulan menggunakan model concept attainment dalam pembelajaran matematika materi bangun ruang di kelas V. Untuk penerapan model concept attainment itu sendiri, mengajak siswa menemukan konsep dengan melakukan analisis contoh yang diberikan guru agar siswa memahami konsep yang dipelajari.

Siswa antusias selama pembelajaran matematika menggunakan model concept attainment karena, dapat mengidentifikasi contoh, memikirkan konsep yang dipelajari dan menyimpulkan hasil diskusi, hal ini relevan dengan penelitian yang dilakukan oleh Habib (2019) yaitu siswa dalam pembelajaran matematika menggunakan model concept attainment lebih antusias dalam belajar, baik menerapkan maupun menghubungkan konsep secara bersamaan, untuk menghasilkan pencapaian yang lebih baik.

Selain itu, langkah-langkah pelaksanaan model concept attainment yang sudah diterapkan di kelas $\mathrm{V}$ yaitu mulai dari (1) tahap penyajian konsep yang tahap ini siswa diberikan sebuah gambar yang diberi label, kemudian dianalisis apa yang didapatkan dari mengamati tersebut, (2) tahap tes pencapaian konsep dalam tahap ini siswa diberikan contoh lagi namun tidak diberi label, kemuduian setelah dianalisis siswa membuat hipotesisnya, dan (3) tahap mengalisis strategi berpikir yaitu siswa bergabung dengan kelompok kemudian mengungkapkan pemikirannya dan menyimpulkannya. Ketiga tahapan tersebut sudah dilakukan oleh guru dan siswa dalam pembelajaran matematika. Hal ini senada dengan yang dikemukakan oleh Joyce dan Weil (2016), yaitu:

1. Fase Satu: Penyajian Data dan Identifikasi Konsep

a. Guru memberikan contoh gambar yang ada label/nama.

b. Siswa mengidentifikasi contoh kemudian menuliskan perbandingan ciri-ciri untuk contoh + dan -.

c. Siswa membuat sebuah hipotesis kemudian, melakukan pengetesan.

d. Siswa mendefinisikan konsep yang didapatkan berdasarkan ciri-ciri utama.

2. Fase Dua: Tes Pencapaian Konsep 
Handayani ${ }^{1}$, \& Hidayati ${ }^{2}$ - Implementasi Model Concept Attainment ...

a. Siswa mengidentifikasi contoh yang tidak diberi label dengan menyatakan ya atau tidak.

b. Guru memberi penegasan mengenai hipotesis, nama konsep, dan mengutarakan kembali definisi konsep sesuai dengan ciri-ciri utama.

3. Fase Tiga: Menganalisis Strategi Berpikir

a. Siswa mengutarakan yang dipikirkannya.

b. Siswa melakukan diskusi mengenai hipotesis dan ciri-ciri konsep yang sudah didapatkan.

c. Siswa melakukan diskusi mengenai tipe dan jumlah hipotesis yang didapatkan.

\section{SIMPULAN}

Berdasarkan pembahasan dapat disimpulkan bahwa, (1) kemampuan pemecahan matematika siswa dengan model concept attainment sudah baik, karena siswa sudah menguasai indikator memahami masalah, merencanakan penyelesaian, melakukan rencana dan melihat kembali, dan hasilnya sebagai berikut S1 dapat menguasai semua indikator untuk 4 soal dari 5 soal yang diberikan, sedangkan S2 dapat menguasai semua indikator untuk 3 soal dari 5 soal yang diberikan, indikator yang paling dimengerti siswa adalah dalam tahapan memahami masalah (menyebutkan apa yang diketahui dan apa yang ditanyakan), merencanakan penyelesaian (merumuskan rumus yang digunakan), dan yang tidak dipahami adalah indikator menyimpulkan hasil dan mengecek kembali jawaban. (2) Pelaksanaan model concept attainment sudah berlangsung selama 3 bulan ntuk pembelajaran matematika materi bangun ruang di kelas V. Langkah-langkah dalam menggunakan model concept attainment sudah dilakukan secara runtut mulai dari tahap penyajian konsep, tahap tes pencapaian konsep dan tahap mengalisis strategi berpikir. Siswa antusias dalam pembelajaran matematika yang sudah menggunakan model concept attainment. Saran untuk siswa lebih banyak berlatih dalam menyelesaikan soal-soal pemecahan masalah matematika dan saran untuk guru yaitu mengoptimalkan pengetahuan matematika dalam pembelajaran menggunakan model concept attainment.

\section{DAFTAR PUSTAKA}

Ahmad, and Susanto. (2013). Teori Belajar Dan Pembelajaran Di Sekolah Dasar. Jakarta: Jakarta : Kencana Prenada Media Group.

Angraini, Lilis Marina. (2019). "The Influence of Concept Attainment Model in Mathematical Communication Ability At the University Students." Infinity Journal 8(2):189.

Anjum, Shaikh Kashefa. (2014). "A Study Of Effect Of Concept Attainment Model On Achievement Of Geometric Concepts Of VIII Standard Students Of English Medium Students Of Aurangabad City Shaikh." SRJIS/Bimonthly 2(15):2451-56.

Bhargava, Ruchi. (2015). "Effect of Concept Attainment Model on Achievement in Social Sciences." International Journal of Science and Research (IJSR) 5(5):699-701.

Habib, Hadiya. (2019). "Effectiveness of Concept Attainment Model of Teaching on Achievement of XII Standard Students in Social Sciences." Shanlax International Journal of Education 7(3):11-15.

Joyce, Bruce, and Marsha Weil. (2000). Models of Teaching. Amerika: Amerika : A. Person Educational Company.

Joyce, Bruce, Marsha Weil, and E.C. (2016). Models of Teaching (Ninth Edition) (9th Ed.). Yogyakarta: Yogyakarta : Pustaka Pelajar.

Kaur, Rajwinder. (2018). "To Study the Effectiveness of Concept Attainment Model of 
Teaching on Achievement of Secondary School Students in Chemistry." Scholarly Research Journal for Humanity Science \& English Language 5(25).

Kholifah, Desi, and Eko Setyadi Kurniawan. (2016). "Pengaruh Model Pembelajaran Concept Attainment Berbasis Masalah Terhadap Pemahaman Konsep Dan Minat Belajar Siswa Kelas XI SMA Negeri 8 Purworejo Tahun Pelajaran 2015 / 2016." Universitas Muhammadiyah Purworejo 9(2):54-58.

Kiswandi, Edy Soedjoko, and Putriaji Hendikawati. (2013). “Komparasi Model Pembelajaran Concept Attainment Dan Cognitive Growth Terhadap Kemampuan Pemahaman Konsep." Unnes Journal of Mathematics Education. 2(3).

Kumar, Amit, and Madhu Mathur. (2013). "Pengaruh Model Pencapaian Konsep Pada Akuisisi Konsep Fisika." 1(3):165-69.

Magdalena, Theresia, and Edy Surya. (2018). "Pengaruh Model Pembelajaran Means Ends Analysis Terhadap Kemampuan Pemecahan Masalah Matematika Siswa Pada Kelas X SMA Swasta Bhayangkari Rantauparapat." Prosiding Seminar Nasional SINASTEKMAPAN I(November):1165-73.

Muhammad, Nazar, Djufri, and Muhibbudin. (2014). "Penerapanmodel concept attainment terhadap hasil belajar siswa padamaterimetabolisme." Jurnal Biologi Edukasi 6(1):9-15.

Munir, Dini Arfiyansyah, and Dewi Sundari. (2017). “Pengaruh Pembelajaran Concept Attainment Model (CAM) Terhadap Kemampuan Berpikir Kritis Siswa Di SMA Nahdatul Ulama (NU) Palembang." 2(2).

NCTM. (2000). Principles and Standards for School Mathematics. Reston: Reston VA : NCTM.

Polya, G. (2004). How to Solve It Mathematical Method. New Jersey: Princeton University Press: New Jersey: Princeton University Press.

Putri, Dini Palupi.(2017). “Model Pembelajaran Concept Attainment Dalam Meningkatkan Pemahaman Konsep Matematika." Jurnal Tatsqif 15(1):97-130.

Sijabat, Fransisca Theresia, Effie Efrida Muchlis, Nurul Astuty Yensy B, (2019) Program Studi, and Pendidikan Matematika. "Penerapan Model Pembelajaran Concept Attainment Untuk Meningkatkan Aktivitas Matematika Siswa SMP." 3(1). 